\title{
'Publication by press conference’ under fire
}

Paris. Worldwide media coverage of claims by researchers at the Pasteur Institute in Paris that they have identified the 'door' through which HIV infects cells - thus opening the way to possible new treatments and a vaccine for AIDS - has lead to renewed calls from scientists for their colleagues to stop announcing 'breakthroughs' at press conferences before they have published their data.

Ara Hovanessian and his colleagues at the institute claimed at a press conference in Paris that CD26, an enzyme that is specific for dipeptide bonds containing the amino acid proline, and which is found on the surface of human $T$ cells (the targets for HIV infection), is essential for assisting the entry of HIV together with the T-cell surface receptor CD4.

According to the French group, CD26 cleaves the HIV envelope protein gp120 at the V3 loop region as the virus attaches to the cell surface. They claim that enzyme inhibitors and antibodies to CD26 block the entry of HIV-1 and HIV-2 into human cells, and that expression of both CD 4 and CD2 is needed for virus entry into mouse cells that do not normally express these molecules.

The claims, which are made in a paper that has been submitted to Science, were made public at a press conference on the first day of the three-day "Cent Gardes" AIDS colloquium at Marne-la-Coquette near Paris. They immediately captured headlines worldwide (including major stories in Le Monde and The New York Times and the London Evening Standard).

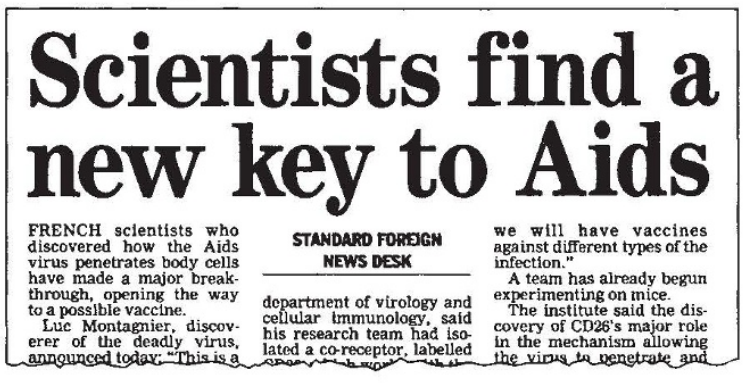

From the London Evening Standard of 26 October.

Hovanessian says that it was "unfortunate" that his findings were given such wide exposure and maintains that he had no choice but to present his findings at the colloquium as they had already been "leaked".

But Hovanessian also agrees that he gave an interview to the news agency Agence France Presse several hours ahead of the press conference. Both Hovanessian and Luc Montagnier, the head of the Pasteur's AIDS research unit, were quoted in newspaper articles as describing the finding as a major breakthrough that could lead to new

\section{MRC to limit patents on CDNA sequences}

London. Britain's Medical Research Council has announced that it will no longer seek to patent cDNA sequences of unknown function. It claims that its initial bid for patent protection on these sequences was made simply to protect British interests if an earlier application from the US National Institutes of Health $(\mathrm{NIH})$ had proved to be successful.

The original bid from the NIH provoked widespread protests from those in the scientific community who argued that it would immediately turn all knowledge of the human genome into private property. In summer last year, however, the latter application was rejected by the US Patent Office on the grounds that it did not meet the necessary criteria for patentability.

The MRC says that it intends to carry on with its own original patent application. In particular, it is keen to receive a ruling from the European Patent Office on whether the application is legally acceptable. And it is also continuing to encourage patent applications on gene sequences where the function is known (a move which itself is still criticized by some scientists).

But in order to show support for the US Patent Office decision, the MRC says that no new patent application will be filed "at present" for sequences where the function is not known. As a result, all sequences obtained at its Human Genome Resource Centre will be transferred directly into DNA databases.

David Owen, director of technology transfer for the MRC, says that he hopes rulings from the US and European patent offices will discourage further applications based only on sequence data.

D.D.

treatments and vaccines. Both also defend the decision to go public, saying that information on AIDS should be released quickly.

But Simon Wain-Hobson, a researcher working in another AIDS group at the Pasteur Institute, describes the data that Hovanessian presented on the second day of the conference as "totally unconvincing". Paul Maddon, chief executive officer of the New York company Progenics Pharmaceuticals Inc. - and who cloned the gene for CD4 and showed that it was the receptor for HIV says that "it suggests a role for CD26 but is not definitive proof".

Both Wain-Hobson and Maddon are concerned that, if CD26 is shown to have no role in HIV infection, it will harm both the public and the credibility of AIDS research. Such credibility, they say, is already low because of the anticlimax that followed widespread publicity of "rumours" of the success of the Salk therapeutic vaccine marketed by Immune Response Corporation (as well as the publication in Nature of a multidrug therapeutic strategy which was later retracted).

Hovanessian and Montagnier are both staking their reputations on CD26. Hovanessian admits that he failed to convince his audience at the conference: "We were convinced ourselves. It wasn't a matter of convincing [others]; it was a matter of believing." Montagnier says he has read carefully the manuscript submitted to $\mathrm{Sci}$ ence. "I am very convinced", he says.

But Wain-Hobson argues that the judgement of scientific results should not be left to individual scientists, particularly in AIDS research. His prediction that similar incidents would occur within twelve months was borne out even sooner. Last weekend, a group in Marseilles made headlines after announcing at a press conference that they had discovered a peptide that blocked entry of HIV into cells in vitro. Declan Butler

\section{German stalemate on nuclear power}

Munich. The future of nuclear energy in Germany has been threatened by the breakdown last week of negotiations between the coalition government and the opposition Social Democrats.

The national executive of the Social Democrat Party (SPD) rejected a compromise worked out by the environment minister, Klaus Töpfer, and the SPD's Gerhard Schröder that would have allowed the development of extra-safe nuclear reactors, even though the SPD had agreed in 1986 to a complete non-nuclear energy policy.

The SDP has now accused Schröder of trying to sell his own party an "ambivalent strategy". The coalition government in turn accuses the SPD of undermining a fundamental aspect of the German economy; the country's ailing coal industry depends on subsidies from the nuclear industry and from nuclear energy generators such as RWE, Veba and Siemens KMU.

Negotiations to establish a working life of between 35 and 40 years for existing reactors are also being blocked by the SPD, which objects to the so-called 'long-term interim storage' of nuclear waste. The stalemate means that a new law is unlikely to be passed until after the general elections next October. 